\title{
Investigative News of Online Media
}

\author{
${ }^{1}$ SEPTIAWAN SANTANA KURNIA, ${ }^{2}$ DADI AHMADI, ${ }^{3}$ FIRMANSYAH \\ 1,2,3 Fakultas Ilmu Komunikasi, Universitas Islam Bandung, Jl. Tamansari No. 1, Bandung, Indonesia \\ correspondence author: ${ }^{1}$ septiawansantana@gmail.com
}

\begin{abstract}
An investigative reporting has changed quite rapidly in the last few periods after the development of information technology. The presence of online media encourages the emergence of online journalism. The existence of online journalism, within the framework of online media, gives a certain touch to investigative reporting activities. Investigative reporting developed in online media has managerial uniqueness and certain coverage patterns. The purpose of this study is to illustrate how the management of editorials and online media coverage patterns in Indonesia conducting investigative coverage. Data for this research is obtained through interviews with data analysis using a qualitative approach and a case study method of single case-multilevel analysis. Research subjects (journalism) and research objects (online investigative news) of this study are Detik.com and Tirto. id. The results of the study show that investigative data are at the core of investigative reporting in online media. It can be in the form of direct observation under investigation (disguising) or the disclosure of new facts that have not been revealed before. The online news media in Indonesia, although it relies on the speed, also still takes into account the accuracy and rules of journalism, especially in the coverage of investigations. The online media strategy in reporting investigations is to divide investigative data into several news stories with one theme, but each headline is different according to the investigative reporting to be reported in parts.
\end{abstract}

Keywords: Journalism, Online Media, Investigative Reporting, News Coverage

\section{Introduction}

Online journalism has grown in various regions. Since the 1990s, in Australia, online journalism began to be recognized after the journalists used the internet and websites (Quinn, 1998). In Greece, online journalism encourages higher inter-media competition, while also becoming a way to avoid the tight political and economic control of media owners (Touri, Theodosiadou, \& Kostarella, 2017). In Russia, online journalism has not been fully accepted by various media; each media runs their online journalism differently depending on their managerial policy, organizational culture, external factors, and culture of Russian people (Erzikova \& Lowrey, 2017). In the UK, the expansion of online journalism into a live blogging format within a social media framework for reporting "crisis, politics, and sports", has given a certain nuance to the format and genre of the news (Thorsen \& Jackson, 2018). In China, the development of online journalism is driven by three dimensions of online journalist types, namely a mixed type of party journalism and Western professionalism, populist mobilizer type (advocacy journalist), and entertainment reporter (Xu \& Jin, 2017).

In Malaysia, online journalism (for example, online newspaper) is about to replace the position of print media. Online technology is used as a tool of "survival" in developing the life of journalism in Malaysia through activities of online media business, reporting activities using digital devices, or other information technology gadgets (Othman, Mat Nayan, Tiung, \& Nik Hassan, 2018).

Indonesia has also online journalism. 
After the era of New Order government, the Indonesian press changed since it was no longer controlled by the state. However, the changes did not take place radically. Journalism in Indonesia is still oriented towards community development, namely to build the nation in the fields of education, human rights, fighting the corruption, alleviating poverty, etc. (Pintak \& Setiyono, 2010).

In Indonesia, online journalism has been practiced through a citizen journalism approach. In 1998, when President Soeharto stepped down from the presidency, people started to use online site channel spaces. Internet technology, according to Merlyna Lim ("Contesting Media Power: Alternative Media in a Networked World," 2003), is used as a new medium for democratic conversation (p.273, 275). Now, many big cities in Indonesia have become "cyber-urban", where the infrastructure of various internet access points patterned the networked communication for most urban individual when they do various communications (Lim, 2018). A web forum is used to send information and news about the developments in Indonesia (Seto, 2017) (p.11, 57), Building public awareness about the importance of public participation (Ahmadi, Rachmiatie, \& Nursyawal, 2019). At that time, the seeds for online journalism began to move in the life of Indonesian press. Although the development of Indonesian press in the early decades of 2000 did not have a professional journalism life yet (Anom, 2011), the practice of online journalism had started to work. Since 1998, several groups of media owners have also developed online media (journalism), in addition to controlling various commercial television stations, print media, and entertainment radio networks (Lim, 2011) (Lim, 2012). Multimedia tools are used in online journalism practices (Adzkia, 2015). Various online media have used data journalism although it has not been explored to the fullest (Badri, 2017). The results show that PPM Pulse Position Modulation is the most effective modulation in comparison with others (Basudewa, Bagaskara, Damita, Putra, \& Ahmadi, 2020).

In Indonesia, weekly news magazine Tempo has a reputation for its competence and credibility for investigative reporting. Tempo is serious in making investigative report. Since 1998, according to Zaky Yamani (Abang et al., 2019), Tempo has an investigative report as one of the reporting sections. Nevertheless, it does not mean
Tempo's investigation goes without obstacles. If in the New Order regime, the government restricted freedom of the press, then in the post-New Order era, business and political actors are pressuring the media. For this reason, Tempo's investigative reporting is carried out through a comprehensive legal assessment from the editor, editor in chief, and company's legal lawyer (p.31-32). In terms of editorial management, Tempo has a strong managerial in carrying out investigative reporting activities where a special team is formed consisting of journalists who have certain qualities and capacities (Kunia \& Othman, 2019).

\section{Research Methodology}

This research is qualitative. As it is explained by Denzin \& Lincoln (Denzin \& Lincoln, 2005), this study is intended to illustrate how investigative practices carried out by online media based on reality in the field (p.3-4). In this study, quoting Nicholas W.Jankowski and Fred Wester (Jensen \& Jankowski, 2002), the theory is in the area of the object itself, which in research means the investigative conceptualization of online media would rather be reconstructed based on data findings in the field (p.45). This research uses the qualitative research process shown by Neuman (Neuman, 2014), such as "Acknowledge Social Self, Adopt Perspective, Design Study, Collect Data, Analyze Data, Interpret Data, Inform Others"; the "ongoing" process always open to various findings arise in the field (p.20-22).

This research is also a study of "Qualitative Case Studies", that is, inquiring the investigative patterns of online media in journalistic reporting and its influence in the context of the development of press in Indonesia as explained by Robert E. Stake (Denzin \& Lincoln, 2005) (p.444). Following Neuman's thoughts (Neuman, 2014), this study intends to construct (in a "detailed, varied, and extensive" manner) how online media organizations conduct investigative reporting (p.41).

Therefore, this research collect data from several online media investigative journalists based on the following methods (Woodside, 2010) (p.3).

Research methods attempting to measure ongoing thinking, and thinking by the same person using multiple interviews over several weeks, methods to bring up subconscious thinking, and interviewing 
the multiple participants involved in the thinking/doing under study not only are particularly useful steps, but also they become mandatory if we really want to achieve deep understanding in research on thinking/doing processes in industrial marketing.

\section{Results and Discussion}

\section{Investigative Search and Report of DetikX.com}

Detik.com is one of the digitized print media. Detik.com Editor in Chief, Alfito Deannova (Interview, October 21, 2019) said that detik.com has the enthusiasm, work pattern, perception, and perspective of print media realized in the form of digital or online media. Detik has a portal called DetikX which was originally served to accommodate investigative news; it reveals what was not revealed in short news; and it has deeper, broader, more focused, and sharper writings.

All investigative news in the DetikX editorial was decided through editorial meeting. There are discussion and editorial agreement in reporting the investigation case of "Lantai Surga di Hotel Alexis" (Heaven's Floor at the Alexis Hotel). The theme of revealing the practice of prostitution in Alexis underwent several stages of the process, not immediately decided in the editorial meeting. Every week, detikX publishes at least once in-depth or investigative news. It is quite challenging for DetikX to determine the theme every week. The characteristic of an investigation requires in-depth research and observation that takes quite some time, contrary to the demand for online media that puts forward the speed and quantity of news to get click traffic.

\section{Determining the Investigation Theme of DetikX.com}

DetikX is an investigative news portal includes in the main portal of Detik.com. Detik. com is part of the Trans Corp media group, which also has several other media, including online media and television. Determining the investigative theme of "The Heaven's Floor at the Alexis Hotel" was a joint decision of two media under the Trans.corp, namely Detik. com and Trans7. The determination of the theme is based on polemics in the community regarding political promises delivered during the governor election campaign a while ago. The public demanded the fulfilment of the elected Governor of DKI Jakarta Anies Baswedan to close down one of the places of entertainment that was suspected as the location of prostitution disguised as hotels and bars.

Irwan (interview, October $21^{\text {th }}, 2019$ ) revealed that based on the fact, the editor decided there was something need to be diclosed at Alexis, namely the alleged prostitution. The editorial meeting discussed Alexis's closure demands, from the time of Ahok leadership to Anies, the DKI Jakarta governor on duty. The absence of media trying to investigate this case was the reason why the Alexis's investigation was carried out by a team of two media. In addition, this case had taken public's attention which encouraged the two media to choose the case and performed an immediate investigation and coverage.

\section{Searching for Investigation Data of De- tikX.com}

In reporting the investigation of "The Heaven's Floor at the Alexis Hotel", DetikX investigative reporting team obtained most of the data using a direct undercover investigation. They conducted the coverage with the Trans7 team by posing as potential customers. The investigation team did not use journalism attributes and did not show their identities to anyone. Just like the regular customer, the investigation team entered the Alexis Hotel in inconspicuous clothing. To prove there was a heaven's floor at the Alexis Hotel, the investigation team was equipped with a hidden camera stored to resemble some equipment.

The team searched for investigative data based on data collected from a number of previous reports/news and they tried to prove the truth of those news. News data only reveal the situation of Alexis entertainment-encased prostitution spots in the eyes of those who claimed to have visited it. The investigation team tried to find the truth by witnessing and recording firsthand what Alexis was really like. The results of visiting illustrated how tight the security was and how the transaction was done at the place of entertainment. Alexis is a very private place where no one can just walk in. The investigation team wanted to prove there was indeed something illegal hidden inside the Alexis. Violations of norms and illaudable practices were done in the context of business. Strict and excessive security at the Alexis indicated there were violations or something illegal happened.

The team did not have an internal 
source network; each member of the team really did the interview and observation directly without making things up. Interviews were conducted with several parties in Alexis without being planned in advance. The secret interview was also conducted with several sources on the spot. Since the interviewee did not know the true identity of the investigation team, they gave more open statements. That was how the results of the investigation can be revealed.

The investigation did not conduct a thorough search of Alexis, but rather had a spesific target namely the seventh floor called heaven. The investigation team traced and made observations since they came, entered the Alexis, and finally made transactions with the brothel keeper. The team completed the investigation after obtaining sufficient investigative data needed through empirical observations and secret interviews. To complete the data, the team used the documentation of other reporting/news data and interviewed the Alexis manager to carry out the cover both side function.

\section{Reporting Investigation Data of DetikX. com}

Investigative data is important in news report, but not all investigative data can be stated in the news. The reported investigation data of "The Heaven's Floor at the Alexis Hotel" news was categorized into four parts of reporting, namely: (1) Background Data that aims to explain the background of investigative reporting; (2) Direct Observation is an investigation data obtained empirically and direct observation of the coverage team. This data becomes the spearhead in describing investigative facts in the form of narrative experience as perceived by the journalist's five senses; (3) Figure description is an investigation data in the form of introduction of figures involved in the case disclosure. This fact serves to liven up the narrative about the real situation based on secret interviews; (4) Confirmation of Cover Both Side is data used as a balance from other investigative facts in the form of interview confirmation with the party in charge.

Investigative data are reported narratively through the description based on five senses. Every detail is illustrated through empirical approach by the investigation team to make the report more interesting and get the readers to feel as if they experience it themselves. Again, not all investigative data is reported in the news, for various reasons. After a transaction with a brothel keeper, other investigative data is passed and immediately terminated. The reason for removing this part, Irwan revealed, was in order to carry out the limits of community norms. He explained that the investigative data report was enough to illustrate and prove the existence of prostitution which in disguised as a place of entertainment.

The investigative report of Alexis' disclosure did not stop at the news of the Heaven's Floor at the Alexis Hotel. Detik. com uploaded the follow-up news about investigations on Alexis in series or running. After investigative news appeared on October 23, 2017, Detik.com through its daily news portal ran news with the headlines such as "There is a 'Tiny Swimming Pool' on the 7th Floor of the Alexis Hotel" and "Here Is the Inside of Alexis, Curious?". The Alexis news that was constantly published in Detik got high traffic. Irwan admitted, reporting investigations about the alleged prostitution at Alexis made DKI Jakarta Governor Anies Baswedan finally close down that entertainment place for violating a business permit. The Alexis investigation report was also aired in Trans7 investigative news because there was a cooperation in the news coverage. Trans7 even re-investigated for the second time to get a better and clearer image.

\section{Investigative Search and Report of Tirto.id}

Tirto.id is an online news portal that still runs investigative journalism and produces indepth and investigative news. On its website, the main news related to investigative journalism is a long and in-depth search of a case considered to have irregularities. As an online media, Tirto.id distinguishes its news from other media through in-depth news approaches. News on interviews with investigative journalists born in the United States who conducted an investigation of the political and social situation in Indonesia, Allan Nairn, became a booster of investigations in Tirto.id. The results of Allan Nairn interview which revealed various scenarios in Indonesian politics had become a polemic because it contained various data that cornered several parties including leaders of Indonesian state.

Determining the Investigation Theme of Tirto.id 
The decision to take investigative report at Tirto.id is done through the editorial meeting, but the proposal for coverage can come from anywhere. In reporting the investigation of "Manipulasi Tender Proyek Kapal Listrik PLN" (Tender Manipulation of Electric Ship Project of PLN) the proposed coverage of the investigation came from sources or informants (whistleblowers) who provided data (raw) to one of the editors at Tirto.id. Data regarding the alleged manipulation of tenders in the purchase of electric ship owned by PLN, one of the state-owned enterprises (BUMN) engaged in supplying electricity in Indonesia, made the editorial of Tirto.id consider the case worth investigating. The editorial meeting decided that an investigation will be carried out to confirm data of alleged acts of corruption in the project. Although preliminary data has been received by the editor, Editor in Chief of In-depth Reporting and Investigation Tirto. id, Mawa Kresna (interviewed on October 21, 2019), explained that the reporting team had kept silent the data for quite a long time due to several other coverage themes. Moreover, the data was being silent because the initial data still required confirmation from various parties, especially officials and figures suspected of being perpetrators.

\section{Searching for Investigation Data of Tirto.id}

In the investigative news of "Manipulasi Tender Proyek Kapal Listrik PLN" (Tender Manipulation of Electric Ship Project of PLN), Tirto.id investigative team has several ways to get investigative data. The investigation team delved the data through five sources and five supporting data. The five sources are as follows: (1) The first source is the whistleblower as the main source of information in revealing the alleged tender manipulation. Most of the data comes from the first source; (2) The second source is the PLN internal party; (3) The third source is the internal of the tender company; (4) The fifth source is the figure involved who has just confirmed at the end; (5) The sixth source is an entrepreneur.

Tirto.id confirmed that the five sources are accountable sources. They were not mentioned in the news but disclosed within with the support of other data that corroborated all data sources. Meanwhile, the supporting data consists of:

\section{Data of BPK (The Audit Board/Supreme}

\section{Audit Agency)}

This data is the result of investigation conducted by the team to the BPK commissioner. Data from the first source is data that has not been confirmed. It was fortunate that when the team was doing coverage at BPK, they obtained BPK audit data which showed there were irregularities inside the PLN. The team gained audit data from the commissioners through investigation. The data was considerably compatible with the data from the first source, although it was not as complete as the source data. The investigation came to light when BPK data was received.

\section{News Report of Katadata.co.id}

Tirto.id is not the first party to report the irregularities of the tender project because previously, there was another news found out about the irregularities. Data from the first source was difficult to confirm before the existence of BPK data, but the news of katadata.co.id reinforced the plan that an investigation needed to be conducted. Katadata.co.id's news coverage became one of the benchmarks in starting the investigation. Katadata.co.id's report entitled "Procurement of Floating Power Plants Allegedly Full of Irregularities" revealed some of the project's irregularities but it was not as complete as Tirto.id. Therefore, the investigation was decided to be carried out considering that the first source data was compatible with a number of data including from katadata.co.id. The team made contact with the reporter who wrote the news and matched the data from the first source.

\section{Interview}

For the validity of data source, the team needed to get confirmation from various relevant sources stated in the data. Officials, figures, and institutions were sources that the team continued to pursue to get confirmation of. Tirto.id believed that the source data must be confirmed to related-parties to get the cover both side function in reporting. The team repeatedly requested confirmation from a number of figures involved, but most of them refused to comment and were difficult to find. Secret interviews were also conducted by the team to several supporting sources such as golf course guards, assistants, and drivers.

\section{Pers Conference}

Since the team had difficulty in getting 
confirmation from the parties and related officials, they did everything they could to get it. The team attended a press conference at the Ministry of BUMN where relevant officials were present. But when a question was asked by the team, the relevant officials acted in opposition to and turned to make a legal threat to the journalists. The threat did not scare the team, but the information was considered as an answer from the perpetrators and took it as a balance in investigative news.

\section{Reports of KPK (Indonesia's Corruption Eradication Commission)}

After conducting an investigation and collecting data, including official statements in a press conference, investigative reporting was considered complete. But unexpectedly, before the news was finished, the related officials were dragged down by other corruption cases in the KPK. Although the investigation was not over yet, the news was closed with the statement that the Managing Director of PLN is finally being detained by the KPK.

\section{Reporting Investigation Data of Tirto.id}

Reporting investigative data is not easier than searching the data. Even though all data had been obtained long before the news was published, which was in May 2019, the news report could not be soon published due to political situation. The editor decided to publish the news after the election was finished so that it was not considered a political effort to reduce the electability of one of the candidate pairs or even to be considered a black campaign. The editor has thought it thoroughly and carefully to avoid political accusations.

While waiting to be published, the team repeatedly reconfirmed the sources to make sure the data reporting was factual and confirmed. Some sources even confirmed at the last minutes confirming the data in the news was indeed true. BPK data was also reaffirmed to several parties to test its relation with the statements of the sources. Every data in the reporting needs to be checked and rechecked before being published

The investigative news of "Manipulasi Tender Proyek Kapal Listrik PLN" (Tender Manipulation of the PLN Electric Ship Project) did not mention any of the five main sources who provided important information in the disclosure of the case. The five sources did not want their names revealed in the news (off the record) for the reasons to maintain their safety or not to be involved in the case. The five sources were willing to confirm the information and had no objection with the news being reported, but they did not want their identities being published. Therefore, this investigation was not easy because it should find data from various parties and institutions that can be reported in the news.

How does to report investigative news when the source is being kept confidential? Kresna explained that BPK reports and data could be helpful. Tirto.id which reported investigative data and facts in the news of "Tender Manipulation of the PLN Electric Ship Project" tried not to use anonymous sources. BPK report data is the entry point for investigative reporting. Any data came from the sources can be represented in BPK data and other sources. The source was not willing to be quoted, but the editor did not want an anonymous either. BPK data was used as a reference so that all data source could be confirmed.

Investigative data reported in the news of "Tender Manipulation of the PLN Electric Ship Project" included: (1) Background Data is an investigative data aims at revealing the background of the cases as a connecting line in investigative news report; (2) Investigation Analysis Data is an investigative data aims at showing the investigative results of collected data, both from the sources and other data such as BPK data; (3) Involvement of figures are investigative facts aim at revealing the involvement of figures with the case occurred; involvement of figures are explained in accordance with their respective roles; (4) Confirmation of Cover Both Side is investigative fact aims at explaining the response or confirmation of figures or official involved in the case to fulfill the balanced and cover both side elements in the reporting; (5) Documentation data are investigative facts aim to support data derived from BPK data sources and reports. Documentation data are the complement in the narrative of investigative cases reported.

Investigation case of alleged corruption in the tender for the PLN electric ship project gave rise to many facts but could not yet be reported in a story. The team found many investigative facts from sources that wanted to keep their identities confidential. Some sources even confirmed the truth after the investigation report was published. The 
investigative facts were intentionally 'kept' by the team to delve the case deeper. Kresna even explained that the investigative report published was only covered the surface. They have a lot of investigative data; there was even data about the involvement of major figures in the government. The investigative news on the tender manipulation for the PLN electric ship project will continue running and be published in several sections.

\section{Discussion}

Investigative reports in online media, as those in print, require steps from searching to reporting and news releasing. In news reporting of two online media of Detik.com and Tirto.id, the study found news reporting process and the characteristics of investigative data that are typically possessed in activities of online media.

\section{The Process of Reporting Online Investigation}

The online investigative reporting process has characteristics with stages and elements of activities as figure 1.

The investigative reporting process in online media begins with the Editorial Meeting whose mechanism has been determined in the managerial editorial. This meeting discusses various findings, proposals, suggestions, ideas, which usually bring the issues found as Preliminary Data. Preliminary Data is data from the first source as a basis for investigations. Preliminary Data can come

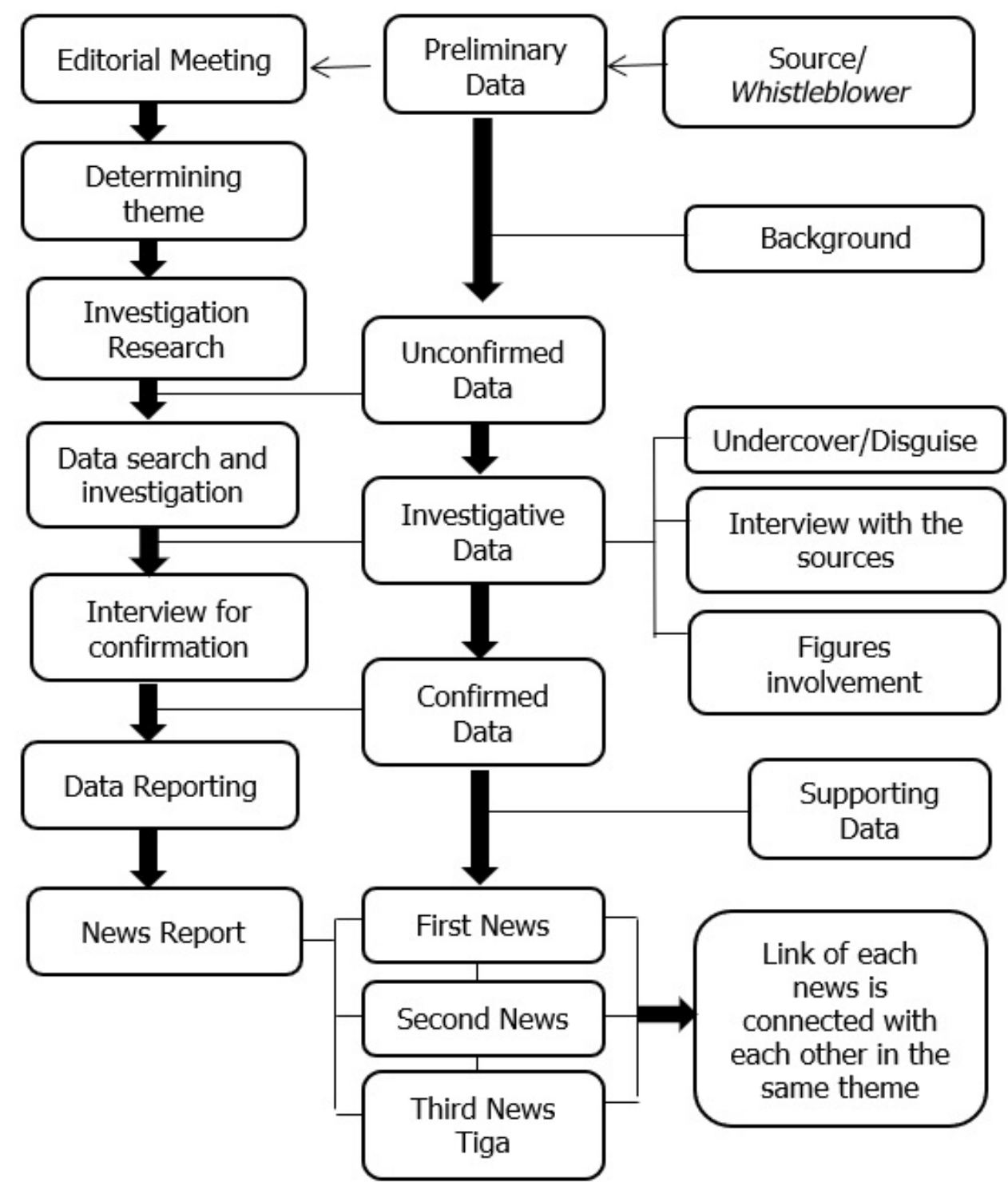

Figure 1. The Process of Reporting Online Investigation 
from various data, either in the form of source information, interviews, report data, news reporting, or even the findings of previous news coverage. These various data are generally obtained from Whistle blower Resources.

In editorial meeting, various editorial members gather to discuss various ideas conveyed. The meeting took place in an atmosphere of warm and mingle and liberating journalistic discussion where various ideas are deliberated one by one. From various discussions, the meeting then determining a theme by the agreement of all editorial members that taken at the end of the meeting and after closing so many bursting ideas. This determined theme already has a database, or issue, which has been filled with various views, statements, facts, and documents.

Investigation Research is the following step of the investigative reporting process in online media. This activity is the beginning, by editorship, of the news reporting of an issue whose theme has been determined earlier. In this research activity, various data, facts, and information are framed into the elements of issue to be explored. On this side, the hypothesis is sometimes set directly in the sense of stipulating, for example, if a hotel has a hidden prostitution activity, then various details of the evidence must be sought to get the conclusion that prostitution, for example, does exist.

In this research activity, the direction is focused on searching and finding unconfirmed data. After getting the preliminary data, the team conducts other data collection that supports initial data as a reference in carrying out the investigation. This data collected is data that must be confirmed in an investigation and involves analyzing background data. This kind of data requires the online media editors to get its validity. The research-stage activities are generally carry out confirmation, clarification or verification. By having the results of research, online media editors conducted a Data Search and Investigation. This stage seems to be an investigative feature of online reporting compared to regular news reporting activities. The investigation process activity in this stage is collecting Investigative Data.

Investigation data obtained by a team or reporters based on the results of an investigation. Investigation data can be in the form of outcome data, observations, investigations, data analysis, or secret interviews. In the online world, investigative activities are carried out through various coverages that are different than the regular coverage. Investigative activities include Disguises, Interview with the Source, and Figure Involvement. Those investigative activities are data collecting related to the direction of the predetermined hypothesis, which is getting proof of the issue to be explored. The various data become a reference for the development of discussion that will be reported in the news.

After establishing various findings, having check and double check all data, and tracing the validity, the next step is Confirmation Interview. In the various interviews at this stage, facts or data findings were dug up again to prove the extent of their strength. Facts or data were assessed to determine whether they are really findings, or need to be explored further, or are likely to have manipulative elements. Therefore, various information obtained during the interview stage here is called Confirmed Data. Investigation data collection must be completed with confirmation in an effort to balance and carry out cover both side functions. Every investigation findings need to be confirmed by relevant parties to get comprehensive data. Confirmation can be done by conducting a direct interview, attending press conference, or getting direct confirmation from the party considered to have represented/given the mandate as a spokesperson.

If it has already completed, confirmed and valid, the next step is to prepare Data Reporting. This activity is the initial writing step before it becomes the news. The complete data should be reported in the news, but not all data is necessary and can be reported. It takes intelligence and good sense of a journalist to manage the data collected in investigative reporting. In the news on Tirto.id, the source is not even mentioned at all, but it still can present a full report. Data reported should contain investigative results that can be enjoyed by readers as a new fact. The placement of data reporting must be adjusted in the right order and can be made as attractive as possible, for example, in the form of inductive reporting, deductive, or both. Data reporting also needs to place each character correctly, both the perpetrator and the source, to explain each role and its relation to the case being reported. Reporting investigative data in online media is unique, that is, the reporting can be divided into 
several news and not limited to just one news report. The nature of report writing has a format and aims to report cases being explored. The form and content of the report is the integrity of issues to be conveyed to the public. Activities in this report include searching various related information.

Thus, in this stage, the activities involve Complementary Data as a comparison, sharpening and expansion of materials for discussion. The confirmed data can be reported as news. However, to change confirmed data into comprehensive data, it is necessary to add other data as a complement. Complementary data can be in the form of graphic data, research data, documentation, or reporting data that completes the confirmed data. Other than that, complementary data is also used to describe each confirmed data in various angles that will make it easier for the reader to understand the results of the investigation and the theme flows inside the news.

News reporting is the last activity at the end of the investigative reporting process. At this stage, the activity focuses on making news from a complete and comprehensive report so that it is adequate to be delivered as news. However, different from print media or broadcast media, online investigative media reports are divided into three news formats, namely: First News, Second News, and Third News. Online characteristics have a "space and time" format that cannot display an investigative case in one long story. The news must be divided into complicated, strong, deep, and interesting formats; this is why news reporting split into three formats. The news reporting has the characteristics that each link is connected to each other in the same theme.

Viewed from the description, the online reporting process has certain characteristics. In general, the online reporting process has basic similarities with other media reporting processes such as print or electronic media. Generally, reporting process in investigative journalism consists of editorial meetings, discussion of issues/news to be published, research and investigative of fact finding, and news reporting activities. In online media investigation, there is an addition to the process, namely a stage called the Confirmation Interview.

This shows that online investigation emphasizes on the coordinated nature of search. Searching investigative data is not directly done in the field, but it is more to confirmation, data checking, or validation. The investigative activity takes place in the process of finding various data, facts, documents, or evidences, which have become public issues and discussion.

Thus, the investigative characteristics of online media give weight to enrichment in public discourse. Online fills in vacancies in public conversation that have not yet been tackled by other media, or have filled in information gaps that have been tackled by other media. The nature of investigative reporting is confirmative, which means that steps taken in investigative reporting are also confirmative. The investigative activity carried out is an attempt to check various cases/ scandals/issues/violations which have become material for reporting in general. These attempts mean investigative efforts that try to establish various public assumptions about problems appear on the surface to become public issues.

This is related to the investigative reporting model carried out by online media. The characteristics of information in online media are "fast, short, concise, and strong (interesting)". Thus, the space and time of online information has the characteristics of reporting that cannot be too long, too slow, and too dull/not interesting. For this reason, investigative reporting in online media is divided into certain narrative formats and packaged in interrelated "link" format.

\section{Characteristics of Investigative Data in Online Media}

The characteristics of virtual online media state the need for unconfirmed data. The "unconfirmed" indicates existing data must be confirmed and be checked first. This means that various investigative issues to be reported have been formed, have become a public discussion, have become a public conversation and public issues. Various data and facts are already exist and only need to be explored further.

Various data are used as materials for online investigative activities and reference for investigative data search activities, data based on investigations results, observational data or investigations, data analysis, or secret interviews.

From this point of view, investigative data reporting in online media raises the character of Confirmed Data. Confirmed data 
has implications for investigative activities in the form of confirmation. In other words, it is an attempt to search for balanced data from various parties.

To complete the presentation of the news, online screen requires an attractive visual appearance. The complementary Data can answer the need by presenting graphic, documentary, etc. This supplementary data is used intentionally as insertions from various Confirmed Data.

Complementary data also becomes material for Data Reporting activities. Various news subjects must be rearranged and can no longer be in the order of mere conveying the facts or perpetrators of the events, but should be reported in interesting news proposals. This is useful for the final stage of online investigative activities, namely News Reporting. In online media, the news should pay attention to the display of photos and videos, graphics, and illustrations in such a way. News with complete and comprehensive writing cannot be written in one sitting. Online media, which emphasizes on the ongoing of message presentation, requires the news to be divided according to the order of the story in the format of connected links.

\section{Conclusion}

The theme of investigative coverage in online media can be determined by several reasons, but should pay attention to the ones that attract readers the most. The theme considered interesting for investigation can be the current issues, the case under discussion, alleged violations, and corruption. Investigation not only reveals something that is not yet known, but also to uncover and prove the issues and allegations that become polemic in the community

Several online media under study showed that investigative news at least requires background data as a link between stories. Every news that has been divided up will start the investigation data with the background as a connecting line for every new fact reported. Investigative data are at the core of investigative reporting in online media. Investigation data can be in the form of direct observation through an investigation (disguising), or disclosure of new facts. To animate and explain in more detail, the investigation data is complemented by a description of the involvement of a character as an actor in the narrative.
Any investigative data revealed will be closed by the confirmation from figures or officials involved as an effort to meet the balance of cover both side elements. Data sources are equipped with supporting data to strengthen the results of investigations in order to convince the readers of the truth of data revealed. In reporting, investigative news still needs to be balanced to assure that the investigation does not have any intention to corner certain party but only to reveal the truth. Hence, online news media in Indonesia, although it relies on the speed, still takes into account the accuracy and rules of journalism, especially in the investigative coverage.

Investigative report in online media is different from other mass media. Online media have the characteristics of speed in reporting, contrary to the principle of investigation which requires caution and takes a long time. In Indonesia, online media investigations reports are usually divided into several parts. It happens because all investigative facts cannot be reported in a single report. Online media investigative news needs to be ongoing to get traffic or clicks from readers. Therefore, the online media strategy in reporting investigations is by dividing investigative data into several news stories with one theme, but each headline is different according to the investigative news to be reported in parts.

\section{Acknowledgment}

I would like to thank the Institute for Research and Community Service of Universitas Islam Bandung that has helped me with the research fund.

\section{References}

Abang, M., Bienvenue, H., Billing, L., Châtel, F. de, Galf, R., Martín, M., ... Yamani, Z. (2019). How investigative journalism affects media : Tempo (DW Akademi; P. Aldenrath, N. Jurrat, \& A. Mong, Eds.). Bonn, Germany: Deutsche Welle 53110 Bonn Germany.

Adzkia, A. R. S. (2015). Praktik Multimedia dalam Jurnalisme Online di Indonesia. Jurnal Komunikasi, 10(1). https://doi.org/ https://doi.org/10.20885/komunikasi. vol10.iss1.art5

Ahmadi, D., Rachmiatie, A., \& Nursyawal. (2019). Public participation model for public information disclosure. Jurnal Komunikasi: Malaysian Journal of 
Communication, 35(4), 305-321. https:// doi.org/10.17576/JKMJC-2019-3504-19

Anom, E. (2011). The Faces of Indonesian Press From 1999-2011. Jurnal Komunikasi, Malaysian Journal of Communication, 27(1), 101-114.

Badri, M. (2017). Inovasi Jurnalime Data Media Online di Indonesia. In A. Wikan \& D. Hartomo (Eds.), The 3rd Indonesia Media Research Awards \& Summit (IMRAS) 2017 TREN POLA KONSUMSI MEDIA DI INDONESIA TAHUN 2017 (pp. 1-18). Jakarta: Serikat Perusahaan Pers (SPS) Gedung.

Basudewa, M. I., Bagaskara, Z. H., Damita, S. S. A., Putra, R. F., \& Ahmadi, D. (2020). Bit Error Rate performance analysis for Free Space Optic communication. IOP Conference Series: Materials Science and Engineering, 850(1). https://doi. org/10.1088/1757-899X/850/1/012056

Contesting Media Power: Alternative Media in a Networked World. (2003). In N. Couldry \& J. Curran (Eds.), European Journal of Communication (Vol. 20). https://doi. org/10.1177/026732310502000106

Denzin, N. K., \& Lincoln, Y. S. (Eds.). (2005). The Sage of Handbook of Qualitative Research THIRD EDITION (Third Edit). Thousand Oaks, London, New Delhi: SAGE Publication, Inc.

Erzikova, E., \& Lowrey, W. (2017). Russian Regional Media: Fragmented community, fragmented online practices. Digital Journalism, 5(7), 919-937. https://doi. org/10.1080/21670811.2016.1234349

Jensen, K. B., \& Jankowski, N. W. (Eds.). (2002). A Handbook of Qualitative Methodologies for Mass Communication Research. London \& New York: Taylor \& Francis e-Library, 2002. First published 1991 by Routledge.

Kunia, S. S., \& Othman, S. S. (2019). Investigative reporting pattern of tempo weekly news magazine. Humanities and Social Sciences Reviews, 7(1), 19-30. https://doi.org/10.18510/hssr.2019.713

Lim, M. (2011). Democratization \& Corporatization Of Media In Indonesia. Participatory Media Lab At Arizona State University \& Ford Foundation.

Lim, M. (2012). The league of thirteen: Media concentration in Indonesia. Participatory Media Lab Arizona State University Tempe, Arizona United States \& The Ford Foundation.

Lim, M. (2018). Dis/Connection: The Coevolution of Sociocultural and Material Infrastructures of the Internet in Indonesia.
Indonesia, Cornell University Press, 105, 155-172. https://doi.org/https://doi. org/10.1353/ind.2018.0006.

Neuman, W. L. (2014). Social Research Methods: Qualitative and Quantitative Approaches (Seventh Ed). Edinburgh Gate Harlow Essex CM20 2JE England: Pearson Education Limited.

Othman, S. S., Mat Nayan, L., Tiung, L. K., \& Nik Hassan, N. N. (2018). Masa Hadapan Akhbar Malaysia dalam Masyarakat Jaringan (The Future of Malaysian Newspapers in a Network Society). Jurnal Komunikasi: Malaysian Journal of Communication, 34(4), 214-231. https:// doi.org/10.17576/jkmjc-2018-3404-13

Penyiaran, D., \& Aji, B. (n.d.). J. Heru Margianto dan Asep Syaefullah.

Pintak, L., \& Setiyono, B. (2010). The Mission of Indonesian Journalism: Balancing Democracy, Development, and Islamic Values. The International Journal of Press / Politics, XX(X), 1-25. https://doi. org/10.1177/1940161210391784

Quinn, S. (1998). Online journalism in Australia: The Internet and daily newspapers. Ecquid Novi: African Journalism Studies, 19(1), 47-65. https://doi.org/10.1080/0256005 4.1998.9653214

Seto, A. (2017). Netizenship, activism and online community transformation in Indonesia. In Goethe University Frankfurt Frankfurt, Germany. https:// doi.org/10.1007/978-981-10-5397-9

Thorsen, E., \& Jackson, D. (2018). Seven Characteristics Defining Online News Formats: Towards a typology of online news and live blogs. Digital Journalism, 6(7), 847-868. https://doi.org/10.1080/ 21670811.2018.1468722

Touri, M., Theodosiadou, S., \& Kostarella, I. (2017). The Internet's Transformative Power on Journalism Culture in Greece: Looking beyond universal professional values. Digital Journalism, 5 (2), 233-251. https://doi.org/10.1080/21670811.2016. 1166062

Woodside, A. G. (2010). Case Study Researh: Theory. Methods. Practice. United Kingdom ? North America ? Japan India ? Malaysia ? China: Emerald Group Publishing Limited.

Xu, Y., \& Jin, J. (2017). The Hierarchy of Influences on Professional Role Perceptions Among Chinese Online Journalists: A multilevel analysis. Digital Journalism, 5(2), 194-212. https://doi.org/10.1080/ 21670811.2016 .1162662$. 